\title{
PENINGKATAN KEMAMPUAN BERPIKIR KRITIS MATEMATIS SISWA SMA MELALUI MODEL PEMBELAJARAN MATEMATIKA KNISLEY DENGAN METODE BRAINSTORMING
}

\author{
Vini Fitria Khairani ${ }^{1}$, Beni Yusepa Ginanjar Putra ${ }^{2}$ \\ ${ }^{1}$ SMA Negeri 1 Cikidang, Sukabumi \\ vinifitriakhairani56@gmail.com \\ ${ }^{2}$ Universitas Pasundan \\ pyusepa.fkip.pmat@unpas.ac.id
}

\begin{abstract}
ABSTRAK
Penelitian ini bertujuan untuk mengkaji penerapan Model Pembelajaran Matematika Knisley (MPMK) dengan Metode Brainstorming (MB) terhadap pencapaian dan peningkatan kemampuan berpikir kritis matematis. Metode penelitian yang digunakan adalah eksperimen semu, dengan desain kelompok kontrol non ekuivalen. Subyek dalam penelitian ini adalah siswa kelas X MIPA 3 sebagai kelas eksperimen dan siswa kelas X MIPA 4 sebagai kelas kontrol di SMAN 4 Sukabumi. Instrumen yang digunakan adalah soal tes kemampuan berpikir kritis matematis tipe uraian. Analisis data kemampuan berpikir kritis matematis menggunakan Independent sample t-test melalui program SPSS 20.0 for Windows dilanjutkan dengan Scheffé test melalui Microsoft Excel. Berdasarkan hasil analisis data diperoleh kesimpulan bahwa: 1) Pencapaian kemampuan berpikir kritis matematis siswa yang memperoleh (MK, MB) lebih baik daripada siswa yang memperoleh Pembelajaran Biasa, 2) Peningkatan kemampuan berpikir kritis matematis siswa yang memperoleh (MK, MB) lebih baik daripada siswa yang memperoleh Pembelajaran Biasa. Oleh karena itu, (MK, MB) dapat dijadikan salah satu alternatif bagi guru dalam melaksanakan pembelajaran matematika di kelas.
\end{abstract}

Kata Kunci : Model Knisley, Brainstorming, Berpikir kritis

\begin{abstract}
This study aims to examine the application of Knisley Mathematics Learning Model (MPMK) with Brainstorming Method (MB) to the achievement and improvement of mathematical critical thinking ability. The method in this research is quasi experiment with non-equivalent control group design. Subject in this research are the students of X MIPA 3 class in SMAN 2 Sukabumi as the experimental class and the students of X MIPA 4 class in SMAN 2 Sukabumi as the control class. The instrument used in this research are a description of mathematical critical thinking ability test. Data analysis of mathematical critical thinking ability using independent sample t-test through SPSS 20.0 for Windows and continued with Scheffé test use Microsoft Excel as well as questionnaire of mathematical anxiety data analysis, where data is converted into quantitative data with MSI (Method of Successive Interval). Based on the data analysis, it can be concluded that: 1) the achievement of mathematical critical thinking ability students who get MPMK+MB is better than the students who get the Ordinary Learning; 2) the improvement of mathematical critical thinking ability students who get MPMK+MB is better than the students who get the Ordinary Learning; Therefore, the MPMK $+\mathrm{MB}$ can be used as an alternative for teachers in implementing mathematics learning in the classroom..
\end{abstract}

Keywords: Model Knisley, Brainstorming, Critical thinking 


\section{PENDAHULUAN}

Matematika merupakan salah satu mata pelajaran pokok yang diajarkan di setiap jenjang pendidikan. Matematika merupakan cabang ilmu pengetahuan yang memegang peranan penting dalam perkembangan ilmu pengetahuan dan teknologi, yaitu sebagai alat bantu, pembentuk pola pikir dan pembentuk sikap. Menurut Ruseffendi (1991), "Matematika merupakan Queen and Servant of Science", maksudnya adalah matematika selain sebagai ratunya ilmu pengetahuan juga sebagai pelayan untuk melayani kebutuhan ilmu pengetahuan yang lain. Terkait dengan pembelajaran matematika, siswa diberikan berbagai permasalahan yang memerlukan kecermatan, ketelitian, analisis, logika dalam memecahkan suatu persoalan matematika. Proses pembelajaran matematika yang mengoptimalkan semua kemampuan siswa dalam proses pembelajaran menjadi perhatian dunia pendidikan saat ini (Yusepa, Kusumah, Kartasasmita; 2018). Proses dalam memecahkan persoalan tersebut diperlukan kemampuan-kemampuan dasar yang harus dimiliki oleh para siswa agar dapat menghasilkan jawaban-jawaban yang tepat, logis dan dapat dipertanggungjawabkan, salah satunya ialah kemampuan berpikir kritis matematis.

Kemampuan berpikir kritis merupakan salah satu kemampuan penting yang harus dimiliki setiap orang untuk menghadapi berbagai persoalan yang semakin kompleks di zaman modern ini. Peraturan Menteri Pendidikan Nasional Nomor 22 Tahun 2006 tentang Standar Isi pun menyebutkan bahwa "mata pelajaran matematika perlu diberikan kepada semua peserta didik mulai dari sekolah dasar untuk membekali mereka kemampuan berpikir logis, analitis, sistematis, kritis, kreatif dan bekerja sama" (Depdiknas, 2006). Hal ini senada dengan kompetensi muatan matematika yang tercantum dalam Peraturan Menteri Pendidikan dan Kebudayaan tahun 2016 Nomor 21 pada tingkat pendidikan dasar dan menengah yang menyatakan bahwa siswa diharapkan mampu menunjukkan sikap logis, kritis, analitis, cermat dan teliti, bertanggung jawab, responsif, dan tidak mudah menyerah dalam memecahkan masalah (Depdikbud, 2016). Kurikulum 2013 yang menyempurnakan kurikulum 2006, juga menjadikan kemampuan berpikir kritis sebagai kemampuan yang tercantum dalam kompetensi dasar yang harus dikembangkan siswa. Kompetensi dasar tersebut yaitu mampu mentransformasi diri dalam berperilaku jujur, tangguh menghadapi masalah, kritis dan disiplin dalam melakukan tugas belajar matematika.

Berpikir kritis fokus pada meyakini atau melakukan sesuatu, artinya bahwa seseorang yang berpikir kritis tidak hanya percaya begitu saja dengan apa yang diungkapkan orang lain. 
Ennis (Costa, 1985) mendefinisikan," Critical thinking is reasonable, reflective thinking that is focused on deciding what to believe or do", artinya berpikir kritis adalah pemikiran yang masuk akal dan reflektif yang difokuskan untuk memutuskan apa yang harus dipercaya atau dilakukan. Anderson (2003) mengungkapkan bahwa bila kemampuan berpikir kritis dikembangkan maka seseorang akan cenderung untuk mencari kebenaran, berpikir terbuka, dan toleran terhadap ideide baru, dapat menganalisis masalah dengan baik, berpikir secara sistematis, penuh rasa ingin tahu dan dewasa dalam berpikir. Berdasarkan uraian yang telah dikemukakan, dapat disimpulkan bahwa kemampuan berpikir kritis mengarah pada kegiatan berpikir untuk menganalisa suatu gagasan secara sistematis, spesifik, cermat, teliti, dengan menggunakan logika dan bukti sehingga kemampuan berpikir kritis merupakan hal penting yang harus dikembangkan khususnya dalam pembelajaran matematika. Siswa yang berpikir kritis dalam matematika diharapkan dapat menggunakan matematika sebagai cara bernalar (berpikir logis, kritis, sistematis, dan objektif) yang dapat digunakan dalam menyelesaikan masalah, baik masalah dalam kehidupan sehari-hari maupun dalam mempelajari ilmu pengetahuan.

Menurut Kurniasih (2012), berpikir kritis matematis merupakan salah satu kemampuan berpikir tingkat tinggi yang penting dikuasai siswa. Banyak peneliti sudah melakukan penelitian terkait pentingnya berpikir kritis matematis pada setiap jenjang pendidikan mulai Sekolah Dasar, Sekolah Menengah Pertama, Sekolah Menengah Atas, dan Perguruan Tinggi. Beberapa diantaranya adalah Syahbana (2012), Sumaryati dan Sumarmo (2013), Lestari (2014), Setiawan (2015), Anita (2015), Paradesa (2015), Novitasari (2015), Noordyana (2016), Kencanawati dan Irawan (2016), Yanti dan Prahmna (2017), Novtiar dan Aripin (2017), dan Delina, Afrilianto, dan Roheti (2018).

Namun kenyataannya, kemampuan berpikir kritis matematis siswa cenderung belum sesuai dengan yang diharapkan. Fakta di lapangan menunjukkan bahwa kemampuan berpikir kritis matematis masih cenderung rendah. Hal ini dikarenakan siswa masih cenderung belum berhasil menjawab dengan benar dari permasalahan soal-soal non rutin yang diberikan (Tresnawati, Hidayat, dan Rohaeti, 2017). Hasil penelitian Kharisma (2017) menunjukkan bahwa rata-rata tingkat kemampuan berpikir kritis matematis siswa SMK masih tergolong rendah pada hampir semua indikator berpikir kritis.

Guru memiliki peranan penting dalam proses pembelajaran dan dalam meningkatkan pendidikan nasional serta menjadi garda terdepan pendidikan (Yusepa, 2016). Guru harus 
mampu membangkitkan gairah belajar yang menyenangkan dan bisa membangkitkan siswa berani bertanya ketika mendapat kesulitan. Aktivitas siswa dalam proses pembelajaran harus lebih banyak dari gurunya dan jangan sampai terjadi sebaliknya. Menurut Yunita, Rosyana, dan Hendriana (2018), pembelajaran matematika di sekolah pada umumnya siswa hanya memperhatikan saja dan guru yang berperan aktif, dalam pembelajarannya peserta didik jarang dilatih dengan soal-soal yang tidak rutin sehingga siswa tidak terbiasa.

Upaya untuk meningkatkan kemampuan berpikir kritis matematis siswa memerlukan berbagai cara pengembangan dalam proses belajar matematika, salah satunya yaitu dengan menerapkan model ataupun metode yang melatih siswa aktif dalam proses pembelajarannya. Salah satu model pembelajaran yang membuat siswa berpartisipasi secara aktif dan secara tidak langsung dapat meringankan beban siswa dalam mengikuti pembelajaran, serta siswa dapat belajar dalam suasana yang menyenangkan adalah Model Pembelajaran Matematika Knisley. Hasil penelitian Romadhoni (2016), Sefieni, Masrukan, dan Zaenuri (2016), Sunanti, Sagita, dan Saputra (2017), Nur (2017), dan Indriani dan Septiana (2018) menunjukkan bahwa Model Pembelajaran Matematika Knisley efektif dan dapat meningkatkan kemampuan matematis siswa. Agar penerapan model pembelajaran ini lebih efektif, maka dalam pelaksanaannya dikolaborasikan dengan Metode Brainstorming. Metode ini sangat tepat digunakan dalam pembelajaran matematika, karena dalam metode ini dapat merangsang siswa untuk mengemukakan pendapat sehingga setiap siswa dapat mengemukakan ide kreatif dalam penyelesaian soal-soal (Triana, 2019).

Model pembelajaran ini memiliki empat tahapan, yaitu alegori, integrasi, analisis, dan sintesis (Mulyana, 2009). Tahapan MPMK dengan Metode Brainstorming dapat dilihat pada Gambar di bawah ini:

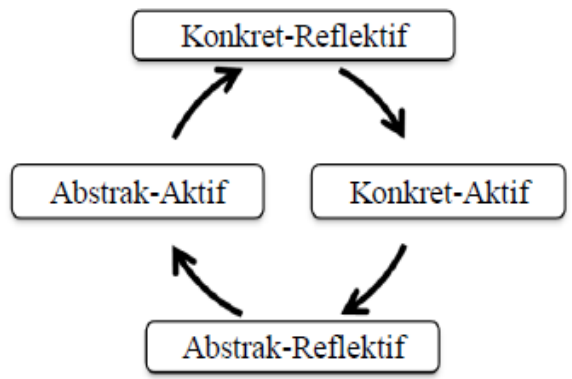

Gambar 1. Siklus MPMK dengan Brainstorming 
Tahap konkret-reflektif dan tahap abstrak-reflektif guru relatif lebih aktif sebagai pemimpin, sedangkan pada tahap konkret-aktif dan abstrak-aktif siswa lebih aktif melakukan eksplorasi dan ekspresi kreatif sementara guru berperan sebagai mentor, pengarah, dan motivator. MPMK melatih proses berpikir siswa dari tahap alegori ke tahap sintesis, dengan ini siswa akan membangun sendiri pengetahuannya. Tingkat keaktifan siswa dan guru saling bergantian, di setiap tahap pembelajaran siswa diberi kesempatan untuk bertanya dan guru mengarahkan aktivitas untuk memperoleh jawaban atau meminta siswa lain untuk menjawabnya. Hal ini berarti bahwa MPMK memberikan ruang kepada siswa untuk terlibat aktif dalam pembelajaran. Ini juga berarti bahwa peran guru dalam setiap langkah sebagai pencerita, pembimbing dan motivator, narasumber, dan pelatih memberikan ruang kepada siswa untuk mengeksplor semua pertanyaan, ide, pendapat, maupun pernyataannya. Siswa akan merasa lebih dihargai, bangga, dan berhasil karena semua pertanyaan, ide, pendapat, maupun pernyataannya diapresiasi dengan baik oleh guru dan teman-temannya. Terdapat metode yang dapat menunjang efektifnya MPMK, yaitu Metode Brainstorming. Menurut Roestiyah (2008), Metode Brainstorming adalah suatu teknik mengajar di dalam kelas dengan memberikan suatu masalah ke kelas oleh guru kemudian siswa menjawab atau menyatakan pendapatnya sehingga masalah tersebut berkembang menjadi masalah baru atau dapat diartikan juga sebagai suatu cara untuk mendapatkan banyak ide dari sekelompok manusia dalam waktu yang singkat.

Berdasarkan uraian yang telah dikemukakan, penulis tertarik untuk melakukan suatu penelitian dengan judul "Peningkatan Kemampuan Berpikir Kritis Matematis Siswa SMA melalui Model Pembelajaran Matematika Knisley (MPMK) dengan Metode Brainstorming.

\section{METODE PENELITIAN}

Penelitian ini adalah penelitian kuantitatif. Metode yang digunakan adalah kuasi eksperimen dimana subjek tidak dikelompokkan secara acak tetapi peneliti menerima keadaan subjek apa adanya (Russeffendi, 2010). Penelitian ini hanya melibatkan dua kelompok, dengan menggunakan desain kelompok kontrol non-ekuivalen sebagai berikut (Ruseffendi, 2010):

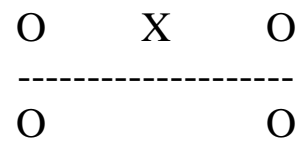


Keterangan:

O : Pemberian tes awal (pretest) dan tes akhir (posttest)

X : Pembelajaran meggunakan MPMK dengan Metode Brainstorming

-----: Subyek tidak dikelompokkan secara acak

Kelompok eksperimen memperoleh Model Pembelajaran Matematika Knisley dengan Metode Brainstorming (MPMK, MB) dan kelompok kontrol memperoleh Pembelajaran Biasa (PB). Kedua kelompok tersebut memperoleh soal (pretest-posttest) matematika.

Populasi dalam penelitian ini adalah siswa kelas X SMAN 2 Sukabumi. Sampel dipilih dua kelas yaitu kelas X MIPA 3 sebagai kelas eksperimen dan kelas X MIPA 4 sebagai kelas kontrol. Instrumen dalam penelitian ini adalah soal kemampuan berpikir kritis matematis sebanyak 5 soal uraian. Teknik pengumpulan data dengan memberikan tes kemampuan berpikir kritis matematis di awal sebelum perlakuan (pretest) dan di akhir setelah selesai perlakuan (posttest). Analisis data kemampuan berpikir kritis matematis menggunakan Independent sample t-test melalui program SPSS 20.0 for Windows dilanjutkan dengan Scheffé test melalui Microsoft Excel.

\section{HASIL DAN PEMBAHASAN}

Bagian ini mendeskripsikan hasil penelitian dan pembahasan yang dihubungkan dengan studi dan teori yang relevan. Data hasil penelitian yang berhasil dikumpulkan berupa data skor pretest dan data skor posttest dianalisis untuk mengetahui ketercapaian dan peningkatannya. Pada penelitian ini taraf kepercayaan yang digunakan adalah 95\% atau $\alpha=5 \%$. Data skor pretest diperoleh dari tes awal yang diberikan sebelum pembelajaran. Skor pretest dari kedua kelas dapat dilihat pada Tabel 1 berikut:

Tabel 1. Statistik Deskriptif Pretest Kemampuan Berpikir Kritis Matematis Kelas Eksperimen dan Kelas Kontrol

\begin{tabular}{cccccc}
\hline \multirow{2}{*}{ Kelas } & $n$ & $x_{\min }$ & $x_{\text {maks }}$ & $\bar{x}$ & $S$ \\
\cline { 2 - 6 } & 37 & 45 & 5 & 20,89 & 9,315 \\
MPMK+MB & 36 & 40 & 4 & 20,50 & 9,358 \\
PB &
\end{tabular}

Berdasarkan data pretest pada Tabel 1, secara umum menunjukkan bahwa rata-rata kemampuan awal berpikir kritis matematis kelas MPMK+MB lebih besar daripada kelas PB, namun perbedaan rata-rata tersebut terlihat kecil. Analisis data skor kemampuan awal berpikir kritis matematis menggunakan uji kesamaan rata-rata data pretest. Uji tersebut bertujuan untuk 
melihat ada tidaknya perbedaan secara signifikan antara kemampuan awal berpikir kritis matematis pada kedua kelas. Sebelumnya dilakukan uji prasyarat terlebih dahulu, yaitu uji normalitas dan homogenitas. Hasil pengujian menunjukkan bahwa data pretest kedua kelas berdistribusi normal dan homogen. Selanjutnya dilakukan uji kesamaan kemampuan awal berpikir kritis matematis dengan uji-t dua pihak melalui Software SPSS 20.0 for Windows menggunakan Independent Sample T-Test. Hipotesisnya dirumuskan dalam bentuk hipotesis statistik (uji dua pihak) menurut Sugiyono (2017) sebagai berikut:

$$
\begin{aligned}
& \mathrm{H}_{0}: \mu_{1}=\mu_{2} \\
& \mathrm{H}_{\mathrm{a}}: \mu_{1} \neq \mu_{2}
\end{aligned}
$$

Perumusan hipotesis komparatifnya sebagai berikut:

$\mathrm{H}_{0}$ : Tidak terdapat perbedaan kemampuan awal berpikir kritis matematis antara siswa yang memperoleh MPMK+MB dan siswa yang memperoleh PB.

$\mathrm{H}_{\mathrm{a}}$ : Terdapat perbedaan kemampuan awal berpikir kritis matematis antara siswa yang memperoleh MPMK+MB dan siswa yang memperoleh PB.

Setelah dilakukan pengolahan, hasil uji-t dapat dilihat pada Tabel 2 di bawah ini:

Tabel 2. Output Uji Kesamaan Kemampuan Awal Berpikir Kritis Matematis

\begin{tabular}{cccc}
\hline \multicolumn{4}{c}{ t-test for Equality of Means } \\
$\mathrm{t}$ & $D f$ & Sig. (2-tailed) & \multirow{2}{*}{ Kesimpulan } \\
\hline .179 & 71 & .858 & $\mathrm{H}_{0}$ diterima \\
\hline
\end{tabular}

Berdasarkan pada Tabel 2 terlihat bahwa nilai signifikansi pada signifikansi (2-tailed) adalah 0,858 . Nilai signifikansi tersebut lebih besar dari 0,05 , maka $\mathrm{H}_{0}$ diterima atau dapat disimpulkan bahwa kemampuan awal berpikir kritis matematis siswa kelas MPMK+MB dan kelas PB tidak berbeda secara signifikan. Selanjutnya untuk melihat ketercapaian kemampuan berpikir kritis matematis kedua kelas dilakukan analisis data posttest, data tersebut diperoleh dari hasil tes akhir yang diberikan setelah pembelajaran. Skor posttest dari kedua kelas dapat dilihat dalam Tabel 3 berikut:

Tabel 3. Data Skor Pencapaian Kemampuan Berpikir Kritis Matematis

\begin{tabular}{cccccc}
\hline \multirow{2}{*}{ Kelas } & \multicolumn{5}{c}{ Tes Akhir (Posttest) } \\
\cline { 2 - 6 } & $n$ & $x_{\operatorname{maks}}$ & $x_{\min }$ & $\bar{x}$ & $S$ \\
\hline MPMK+MB & 37 & 87 & 24 & 59,76 & 16,025 \\
PB & 36 & 78 & 20 & 50,47 & 15,326 \\
\hline
\end{tabular}

Selanjutnya dilakukan uji-t untuk melihat ketercapaian kemampuan berpikir kritis matematis kedua kelas. Sama halnya seperti data pretest, sebelum uji-t terlebih dahulu dilakukan 
uji prasyarat yaitu uji normalitas dan homogenitas. Hasil pengujian menunjukkan bahwa data posttest kedua kelas berdistribusi normal dan homogen. Uji pencapaian kemampuan berpikir kritis matematis dengan uji-t dua pihak melalui Software SPSS 20.0 for Windows menggunakan Independent Sample T-Test. Hipotesisnya dirumuskan dalam bentuk hipotesis statistik (uji dua pihak) menurut Sugiyono (2017) sebagai berikut:

$$
\begin{aligned}
& \mathrm{H}_{0}: \mu_{1}=\mu_{2} \\
& \mathrm{H}_{\mathrm{a}}: \mu_{1} \neq \mu_{2}
\end{aligned}
$$

Perumusan hipotesis komparatifnya sebagai berikut:

$\mathrm{H}_{0}$ : Tidak terdapat perbedaan pencapaian kemampuan berpikir kritis matematis antara siswa yang memperoleh MPMK+MB dan siswa yang memperoleh PB.

$\mathrm{H}_{\mathrm{a}}$ : Terdapat perbedaan pencapaian kemampuan berpikir kritis matematis antara siswa yang memperoleh MPMK+MB dan siswa yang memperoleh PB.

Setelah dilakukan pengolahan, hasil uji-t dapat dilihat pada Tabel 4 di bawah ini:

Tabel 4. Output Uji Pencapaian Kemampuan Berpikir Kritis Matematis

\begin{tabular}{cccc}
\hline \multicolumn{3}{c}{ t-test for Equality of Means } & \multirow{2}{*}{ Kesimpulan } \\
\hline $\mathrm{t}$ & $D f$ & Sig. (2-tailed) & \\
\hline 2.529 & 71 & .014 & Ha diterima \\
\hline
\end{tabular}

Berdasarkan pada Tabel 4 nilai p-valued untuk 2-tailed $=0,014$, karena $p$-value $=0,014$ $<\alpha=0,05$ maka $\mathrm{H}_{0}: \mu_{1}=\mu_{2}$ ditolak dan $\mathrm{H}_{\mathrm{a}}: \mu_{1} \neq \mu_{2}$ diterima, sehingga dapat dikatakan bahwa terdapat perbedaan pencapaian kemampuan berpikir kritis matematis antara siswa yang memperoleh MPMK+MB dengan siswa yang memperoleh PB. Mana yang lebih baik? untuk menjawab pertanyaan tersebut maka dilakukan uji lanjutan dengan menggunakan uji Scheffé melalui Software Microsoft Excel 2010.

Setelah dilakukan perhitungan dengan rumus uji Scheffé, didapat $t_{\text {hitung }}=2,526$. Harga $t_{\text {hitung }}$ tersebut selanjutnya dibandingkan dengan harga $t_{\text {tabel }}$ dengan $\mathrm{dk}=n_{1}+n_{2}-2=37+$ $36-2=71$ pada taraf signifikansi 0.05 didapat $t_{\text {tabel }}=1,994$. Harga $t_{\text {hitung }}=2,526>t_{\text {tabel }}=$ 1,994 sehingga $\mathrm{H}_{0}$ ditolak, karena rata-rata siswa yang memperoleh $\mathrm{MPMK}+\mathrm{MB}$ 59,76 lebih besar dari rata-rata siswa yang memperoleh PB 50,47, maka pencapaian kemampuan berpikir kritis matematis siswa yang memperoleh MPMK+MB lebih baik daripada pencapaian kemampuan berpikir kritis matematis siswa yang memperoleh PB.

Analisis data selanjutnya adalah analisis data peningkatan kemampuan berpikir kritis matematis siswa. Peningkatan kemampuan berpikir kritis matematis siswa kedua kelas dilihat 
dari data indeks gain, data indeks gain dari masing-masing kelas dapat dilihat pada Tabel 5 berikut:

Tabel 5. Data Skor Peningkatan Kemampuan Berpikir Kritis Matematis

\begin{tabular}{cccccc}
\hline \multirow{2}{*}{ Kelas } & \multicolumn{5}{c}{$n$-Gain } \\
\cline { 2 - 6 } & $\mathrm{N}$ & $\begin{array}{c}\text { Nilai } \\
\text { Maksimum }\end{array}$ & $\begin{array}{c}\text { Nilai } \\
\text { Minimum }\end{array}$ & $\begin{array}{c}\text { Rata- } \\
\text { rata }\end{array}$ & $\begin{array}{c}\text { Simpangan } \\
\text { Baku }\end{array}$ \\
\hline MPMK+MB & 37 & 0,80 & 0,16 & 0,5014 & 0,16562 \\
PB & 36 & 0,66 & 0,06 & 0,3856 & 0,15294 \\
\hline
\end{tabular}

Sebelum dilakukan analisis data peningkatan, dilakukan uji prasyarat yaitu uji normalitas dan uji homogenitas. Hasil pengujian menunjukkan data skor peningkatan kedua kelas berdistribusi normal dan homogen. Uji peningkatan kemampuan berpikir kritis matematis dengan uji-t dua pihak melalui Software SPSS 20.0 for Windows menggunakan Independent Sample T-Test. Hipotesisnya dirumuskan dalam bentuk hipotesis statistik (uji dua pihak) menurut Sugiyono (2017, hlm. 120) sebagai berikut:

$$
\begin{aligned}
& H_{0}: \mu_{1}=\mu_{2} \\
& H_{a}: \mu_{1} \neq \mu_{2}
\end{aligned}
$$

Perumusan hipotesis komparatifnya sebagai berikut:

$\mathrm{H}_{0}$ : Tidak terdapat perbedaan peningkatan kemampuan berpikir kritis matematis antara siswa yang memperoleh MPMK+MB dan siswa yang memperoleh PB.

$\mathrm{H}_{\mathrm{a}}$ : Terdapat perbedaan peningkatan kemampuan berpikir kritis matematis antara siswa yang memperoleh MPMK+MB dan siswa yang memperoleh PB.

Setelah dilakukan pengolahan, hasil uji-t dapat dilihat pada Tabel 6 di bawah ini:

Tabel 6. Output Uji Peningkatan Kemampuan Berpikir Kritis Matematis

\begin{tabular}{cccc}
\hline \multicolumn{3}{c}{$t$-test for Equality of Means } & Kesimpulan \\
\hline $\mathrm{t}$ & $D f$ & Sig. (2-tailed) & \\
\hline 3.101 & 71 & .003 & Ha diterima \\
\hline
\end{tabular}

Tabel 6 menunjukkan nilai p-valued untuk 2-tailed $=0,003$, karena $p$-valued $=0,003<$ $\alpha=0,05$ maka $\mathrm{H}_{0}: \mu_{1}=\mu_{2}$ ditolak dan $\mathrm{H}_{\mathrm{a}}: \mu_{1} \neq \mu_{2}$ diterima, sehingga dapat disimpulkan bahwa terdapat perbedaan peningkatan kemampuan berpikir kritis matematis antara siswa yang memperoleh MPMK+MB dan siswa yang memperoleh PB. Peningkatan mana yang lebih baik? untuk menjawab pertanyaan tersebut maka dilakukan uji lanjutan dengan uji Scheffé melalui Software Microsoft Excel 2010. 
Setelah dilakukan perhitungan dengan rumus uji Scheffé, didapat $t_{\text {hitung }}=3,123$. Harga $t_{\text {hitung }}$ tersebut selanjutnya dibandingkan dengan harga $t_{\text {tabel }}$ dengan $\mathrm{dk}=n_{A}+n_{B}-2=37+$ $36-2=71$ pada taraf signifikansi 0.05 didapat $t_{\text {tabel }}=1,994$. Harga $t_{\text {hitung }}=3,123>t_{\text {tabel }}=$ 1,994, sehingga $\mathrm{H}_{0}$ ditolak, karena rata-rata peningkatan kemampuan berpikir kritis matematis siswa yang memperoleh MPMK+MB 0,5014 lebih besar dari rata-rata peningkatan kemampuan berpikir kritis matematis siswa yang memperoleh PB 0,3856, maka peningkatan kemampuan berpikir kritis matematis siswa yang memperoleh MPMK + MB lebih baik daripada peningkatan kemampuan berpikir kritis matematis siswa yang memperoleh PB.

Berdasarkan deskripsi dan hasil analisis data yang telah dipaparkan, diketahui bahwa pencapaian dan peningkatan kemampuan berpikir kritis matematis siswa yang memperoleh (MPMK, MB) lebih baik daripada siswa yang memperoleh PB, bersamaan dengan itu pula kecemasan matematis siswa yang memperoleh (MPMK, MB) menjadi lebih rendah dari sebelumnya. Hal ini menunjukkan makna bahwa MPMK yang ditunjang dengan MB berdampak baik terhadap kemampuan berpikir kritis dan kecemasan matematis siswa. Ini diduga akibat baiknya langkah-langkah pembelajaran (MPMK, MB) yang mendukung siswa untuk aktif dalam proses belajar, sehingga timbul sikap kritis pada diri mereka. Sejalan dengan yang dikemukakan Ruseffendi (2006) strategi atau teknik mengajar diperlukan oleh setiap guru agar yang diperoleh siswa itu semaksimal mungkin.

Sebelum menerapkan (MPMK, MB) dalam pembelajaran, siswa terlihat masih kesulitan untuk memahami, memberikan tanggapan, dan menyelesaikan soal. Mereka lebih suka menyalin pekerjaan teman dan menunggu soal tersebut dibahas secara bersama-sama, dan semangat untuk mengerjakan soal pun terlihat rendah. Penggunaan (MPMK, MB) dalam proses pembelajaran mendorong siswa melakukan kegiatan penemuan, yang mana kegiatan penemuan tersebut meliputi: eksplorasi, percobaan, mengukur, atau membandingkan sehingga dapat membedakan konsep baru dengan konsep-konsep yang telah diketahui nya. Selain itu, bersama guru siswa juga diharuskan mampu membuat atau memilih pernyataan yang terkait dengan konsep baru, memberi contoh kontra untuk menyangkal pernyataan yang salah, dan membuktikan pernyataan yang benar pada saat presentasi di depan. Proses pembelajaran ini sesuai dengan teori belajar Bruner yang dikenal dengan nama belajar penemuan. Salah satu kebaikan belajar penemuan menurut Bruner (Dahar), "pengetahuan yang diperoleh dengan belajar penemuan menghasilkan pengetahuan yang benar-benar bermakna sehingga dapat 
memberikan hasil belajar penemuan yang mempunyai efek transfer yang lebih baik daripada hasil belajar lainnya". Dengan kata lain, konsep dan prinsip-prinsip akan diingat lebih lama melalui proses belajar penemuan.

Proses belajar penemuan mendorong siswa untuk aktif dalam belajar. Keaktifan siswa dalam belajar sangat membantu dalam mencapai keberhasilan belajar di kelas. Keberhasilan siswa dalam pembelajaran, diantaranya tergantung bagaimana cara siswa mengatasi kesulitan (Yudiawati dan G.P, 2017). Hal senada Slameto (2003) menyatakan bahwa salah satu yang mempengaruhi prestasi belajar siswa adalah aktivitas belajar. Alexandra dan Ratu (2018) menyatakan hal senada bahwa hendaknya sering memberikan latihan-latihan soal yang dapat mengasah kemampuan berpikir kritis siswa. Proses pembelajaran dengan MPMK mengajak siswa untuk menggali semua potensi yang dimiliki dan memahami konsep dari proses terbentuknya hingga proses penerapannya dalam latihan soal. Siswa dapat menilai sebuah rumus, konsep dan pernyataan itu benar atau keliru dari sudut pandang proses menemukannya, karena seringkali terjadi perbedaan pendapat dalam proses belajar yang disebabkan oleh perbedaan rumus antar satu sumber dengan sumber lainnya.

Keunggulan MPMK juga terletak ketika guru melakukan tahap abstrak-aktif yang ditunjang dengan MB dimana guru memberikan ruang dan kesempatan lebih luas kepada siswa untuk bebas menyampaikan ide, pendapat, gagasan dan apapun yang ada di pikirannya tanpa ada rasa takut untuk di kritik atau disanggah pemikirannya itu, membuat siswa menjadi lebih berani dan percaya diri, sehingga mengurangi rasa cemas yang ada pada diri mereka, lalu kemudian mempresentasikannya di depan kelas. Setelah presentasi konsep yang mereka temukan digunakan untuk mengerjakan soal latihan. Hal ini sejalan dengan Smith (Mulyana), yang menyatakan bahwa pembelajaran matematika yang mengembangkan setiap gaya belajar Knisley berarti mengaktifkan semua bagian otak sehingga pembelajaran menjadi lebih efektif.

Pembelajaran berjalan dengan baik walaupun pada pertemuan pertama siswa masih terlihat kaku karena tidak terbiasa dengan pembelajaran (MPMK, MB) yang diberikan, namun pada pertemuan berikutnya umumnya terjadi peningkatan aktivitas siswa. Siswa lebih banyak bertanya dan menjawab pertanyaan baik itu pertanyaan dari guru ataupun dari temannya sendiri. Selain itu, proses ini pun secara tidak langsung membuat siswa menjadi lebih mandiri dalam belajar, dengan adanya pengelompokan pula siswa menjadi lebih aktif untuk mengeluarkan ideide dan menanggapi ide-ide dari teman sekelompoknya maupun dari kelompok lain. Hal ini 
sejalan dengan pernyataan Yusepa (2016), Widiawati dan Koswara (2016), Rosita dan Jenudin (2017), dan Yusepa, Kusumah, dan Kartasasmita (2018), membangun konsep matematis secara mandiri oleh siswa merupakan hal yang mendasar dalam pembelajaran matematika. Siswa diberikan kesempatan yang seluas-luasnya untuk membangun dan mengkonstruksi sendiri pengetahuannya. Sehingga siswa akan memiliki kemampuan matematis dari yang sederhana sampai yang paling kompleks.

\section{KESIMPULAN}

Berdasarkan uraian hasil dan pembahasan yang telah dikemukakan, diperoleh beberapa kesimpulan sebagai berikut: 1) Pencapaian kemampuan berpikir kritis matematis siswa yang memperoleh Model Pembelajaran Matematika Knisley (MPMK) dengan Metode Brainstorming (MB) lebih baik daripada siswa yang memperoleh pembelajaran biasa, 2) Peningkatan kemampuan berpikir kritis matematis siswa yang memperoleh Model Pembelajaran Matematika Knisley (MPMK) dengan Metode Brainstorming (MB) lebih baik daripada siswa yang memperoleh pembelajaran biasa.

\section{REFERENSI}

Alexandra, G. dan Ratu, N. (2018). Profile of Mathematical Thinking Skills Junior High School Students with Graded Response Models. Jurnal Musharafa, 7(1).

Anita, I.W. (2015) Pengaruh Motivasi Belajar Ditinjau Dari Jenis Kelamin Terhadap Kemampuan Berpikir Kritis Matematis Mahasiswa. Jurnal Ilmiah UPT P2M STKIP Siliwangi, 2(2).

Anderson, J.A. (2003). Critical Thinking Across the Disciplines. Makalah pada Faculty Development Seminar in New York City College of Technology, New York.

Costa, A.L., (1985). Developing Minds: A Resource Book for Teaching Thinking. Alexandria: ASCD.

Dahar, R. W. (2011). Teori-teori belajar dan pembelajaran. Jakarta: Erlangga.

Delina,1, Afrilianto, M., Rohaeti, E.E. (2018) Kemampuan Berpikir Kritis Matematis Dan Self Confidence Siswa SMP Melalui Pendekatan Realistic Mathematic Education. Jurnal Pembelajaran Matematika Inovatif, 1(3). 
Depdikbud. (2016). Permendikbud No. 21 Tentang Standar Isi Pendidikan Dasar dan Menengah. Jakarta: Kementerian Pendidikan dan Kebudayaan. Tersedia di https://luk.staff.ugm.ac.id/atur/bsnp/Permendikbud21-2016SIDikdasmen.pdf.

Depdiknas. (2006). Permendiknas nomor 22 tahun 2006 tentang standar isi sekolah dasar. Jakarta: Depdiknas. Tersedia di https://asefts63.files.wordpress.com /2011/01 /permendiknas-no-22-tahun-2006-standar-isi.pdf.

Fariha, M. (2013). Kemampuan Berpikir Kritis Matematis dan Kecemasan Matematika dalam Pembelajaran dengan Pendekatan Problem Solving (Studi Eksperimen Pada Kelas X Man Rukoh Kota Banda Aceh). Jurnal Peluang. 1(2). 43-50.

Hendriana, H. (2018) Analisis Kemampuan Berpikir Kritis Matematis Berdasarkan Motivasi Belajar Matematis Siswa SMP. Jurnal Pembelajaran Matematika Inovatif, 1(3).

Irawan, A. dan Kencanawati, G. (2016). Peranan Kemampuan Verbal dan Kemampuan Numerik terhadap Kemampuan Berpikir Kritis Matematika. Aksioma, 5(2).

Kharisma, E.N (2018) Analisis Kemampuan Berpikir Kritis Matematis Siswa SMK Pada Materi Barisan dan Deret. JRPM, 3(1), 62-75.

Kurniasih, A. W. (2012) Scaffolding sebagai Alternatif Upaya Meningkatkan Kemampuan Berpikir Kritis Matematika. Jurnal Formatif, 4(3).

Lestari, E.K. (2014) Implementasi Brain-Based Learning untuk Meningkatkan Kemampuan Koneksi dan Kemampuan Berpikir Kritis serta Motivasi Belajar Siswa SMP. Jurnal Pendidikan Unsika, 2(1).

Madyaning, E. dan Romadhoni, C. (2016) Implementasi Model Pembelajaran Matematika Knisley (MPMK) dalam Upaya Meningkatkan Kemampuan Komunikasi Matematis Siswa Dan Respon Siswa dalam Pembelajaran. Konferensi Nasional Penelitian Matematika dan Pembelajarannya (KNPMP I), Universitas Muhammadiyah Surakarta.

Mulyana, E. (2009.). Pengaruh Model Pembelajaran Matematika Knisley terhadap Peningkatan Pemahaman dan Disposisi Matematika Siswa Sekolah Menengah Atas Program Ilmu Pengetahuan Alam. Diakses dari laman web tanggal 11 Oktober 2017 Tersedia: http://file.upi.edu/Direktori/fpmipa/jur.pend.matematika/195401211979031endangmulyana/makalah/Artikel_ Jurnal PASCA_UPI.pdf. 
Noordyana, M.A. (2016) Meningkatkan Kemampuan Berpikir Kritis Matematis Siswa melalui Pendekatan Metacognitive Instruction. Jurnal Mosharafa, 5(5).

Novitasari, D. (2015) Penerapan Pendekatan Pembelajaran Creative Problem Solving (Cps) Sebagai Upaya Meningkatkan Kemampuan Berpikir Kritis Matematis Siswa. FIBONACCI: Jurnal Pendidikan Matematika \& Matematika, 1(1).

Novtiar, C dan Aripin, U (2017) Meningkatkan Kemampuan Berpikir Kritis Matematis dan Kepercayaan Diri Siswa SMP melalui Pendekatan Open Ended. PRISMA, 6(2).

Nur (2017) Pengembangan Bahan Ajar Matematika Kelas VII SMP berdasarkan Model Pembelajaran Kolb-Knisley Berbantuan GeoGebra sebagai Upaya Meningkatkan Higher-Order Thinking Skill dan Apresiasi Siswa terhadap Matematika. MaPan: Jurnal Matematika dan Pembelajaran, 5(1).

Rodianawati, L. (2017) Perbandingan Koneksi Matematika Siswa Antara Yang Menggunakan Model Pembelajaran Discovery Learning Dengan Model Pembelajaran Knisley. Jurnal Euclid, 3(2), 548

Roestiyah NK. (2008). Strategi Belajar Mengajar. Jakarta: PT. Rineka Cipta.

Rosita, N. T., dan Jaenudin A (2017). "Implementasi Pembelajaran Matematika dengan Pendekatan Open Ended terhadap Sikap Siswa”. Symmetry: Pasundan Journal of Research in Mathematics Learning and Education, 1(1), 1-12.

Ruseffendi, E.T. (1991). Pengantar kepada Membantu Guru Mengembangkan Kompetensinya dalam Pengajaran Matematika untuk Meningkatkan CBSA. Bandung: Tarsito.

Ruseffendi, E.T. (2005). Dasar-Dasar Matematika Modern dan Komputer Untuk Guru. Bandung: Tarsito.

Ruseffendi, E.T. (2006). Pengantar kepada Membantu Guru Mengembangkan Kompetensinya dalam Pengajaran Matematika untuk Meningkatkan CBSA. Bandung: Tarsito.

Ruseffendi, E.T. (2010). Dasar-Dasar Penelitian dan Bidang Non-Eksakta Lainnya. Bandung: Tarsito.

Paradesa, R. (2015) Kemampuan Berpikir Kritis Matematis Mahasiswa Melalui Pendekatan Konstruktivisme Pada Matakuliah Matematika Keuangan. Jurnal Pendidikan Matematika JPM RAFA, 1(2). 
Sefiany, N., Masrukan, dan Zaenuri (2016) Kemampuan Komunikasi Matematis Siswa Kelas VII Pada Pembelajaran Matematika Dengan Model Knisley berdasarkan Self Efficacy. UJME, 5 (3).

Septiana, W., Indriani, A.N., (2018). Model Pembelajaran Knisley Untuk Meningkatkan Kemampuan Pemahaman Konseptual Matematis Siswa SMP. Kalamatika. Jurnal Pendidikan Matematika, 3(2), 155-174.

Slameto. (2003). Belajar dan Faktor-faktor yang mempengaruhinya. Jakarta: Bumi Aksara.

Sugiyono. (2017). Statistika untuk Penelitian. Bandung: Alfabeta.

Sumaryati, U dan Sumarmo, U. (2013) Pendekatan Induktif-Deduktif Disertai Strategi ThinkPair-Square-Share Untuk Meningkatkan Kemampuan Pemahaman Dan Berpikir Kritis Serta Disposisi Matematis Siswa SMA. Infinity: Jurnal Ilmiah Program Studi Matematika STKIP Siliwangi Bandung, 2(1).

Sunanti, T., Sagita, L., Saputra, I.D., (2017) Knisley Untuk Komunikasi Matematika. Aksioma, $8(2)$.

Syahbana, A. (2012) Peningkatan Kemampuan Berpikir Kritis Matematis Siswa SMP melalui Pendekatan Contextual Teaching and Learning. Edumatica, 02(01).

Tresnawati, I., Hidayat, W., dan Rohaeti, E.E. (2017) Kemampuan Berpikir Kritis Matematis dan Kepercayaan Diri Siswa SMA. Symmetry: Pasundan Journal of Research in Mathematics Learning and Education, 2(2).

Triana (2019) Penerapan Model Cycle Learning 5e Dan Metode Brainstorming Terhadap Kemampuan Komunikasi Matematis Ditinjau Dari Motivasi Belajar Siswa Pada Materi Segi Empat. $\delta$ ELTA: Jurnal Ilmiah Pendidikan Matematika, 7(1).

Widiawati, A. S., dan Koswara, U. (2016). Implementasi Model Pembelajaran Resource Based Learning Berbantuan Program GeoGebra Dalam Upaya Meningkatkan Kemampuan Pemahaman Konsep Matematis. Symmetry: Pasundan Journal of Research in Mathematics Learning and Education, 1(1), 67-78.

Yanti, O. F., Prahmana, R.C.I. (2017) Model Problem Based Learning, Guided Inquiry, dan Kemampuan Berpikir Kritis Matematis. JRPM, 2(2), 120-130.

Yusepa, B. (2016). Kemampuan abstraksi matematis siswa Sekolah Menengah Pertama (SMP) KLS VIII. Symmetry: Pasundan Journal of Research in Mathematics Learning and Education, 01(01), 54-60. 
Yusepa, B.G.P. (2016). Analisis Perbandingan Kurikulum Pendidikan Indonesia dan Inggris untuk Meningkatkan Kompetensi Pedagogik dan Kompetensi Profesional Guru Matematika. Prosiding Seminar Nasional Matematika dan Pendidikan Matematika: Strategi Mengembangkan Kualitas Pembelajaran Matematika Berbasis Riset. Unswagati. Hal. 346- 364. ISBN: 978-602-71252-1-6.

Yudiawati, N., \& G. P, B. Y. (2017). Penerapan Model Pembelajaran Cooperative Script untuk Meningkatkan Kemampuan Berpikir Kreatif Matematis Sekolah Menengah Pertama (SMP). TEOREMA: Teori dan Riset Matematika, 2(1), 63-72.

Yusepa, B. G. P., Kusumah, Y. S., and Kartasasmita, B. G. (2018). The enhancement of students' mathematical representation in junior high school using cognitive apprenticeship instruction (CAI). J. Phys.: Conf. Ser. $\mathbf{9 8 3} 012100$.

Yusepa, B. G. P., Kusumah, Y. S., and Kartasasmita, B. G. (2018). Promoting middle school students' abstract thinking ability through cognitive apprenticeship instruction in mathematics learning. J. Phys.: Conf. Ser. 948012051. 